\title{
Coulisses
}

Revue de théâtre

3 | Hiver 1991

Théâtre et université

Théâtre et engagement

\section{El cojo de Ernst Töller}

\section{Rédaction}

\section{(2) OpenEdition}

\section{Journals}

Édition électronique

URL : http://journals.openedition.org/coulisses/1638

DOI : 10.4000/coulisses. 1638

ISSN : 2546-9460

\section{Éditeur}

Presses universitaires de Franche-Comté

\section{Édition imprimée}

Date de publication : 1 février 1991

Pagination : 27

ISSN : 1150-594X

Référence électronique

Rédaction, «El cojo de Ernst Töller », Coulisses [En ligne], 3 | Hiver 1991, mis en ligne le 04 juillet 2017, consulté le 26 octobre 2019. URL : http://journals.openedition.org/coulisses/1638 ; DOI : 10.4000/ coulisses. 1638

Ce document a été généré automatiquement le 26 octobre 2019

Coulisses 


\title{
Théâtre et engagement
}

\section{El cojo de Ernst Töller}

\author{
Rédaction
}

Quelle est l'histoire?

Cette pièce est d'un auteur allemand qui s'appelle Ernst Töller. C'est un expressionniste mort en 1933. Il a écrit cette pièce en prison car il était un révolutionnaire.

C'est une pièce sur la condition humaine dans la révolution. C'est le cas individuel d'un homme qui pendant la guerre a été castré. Il est marié, et quand il revient chez lui, il a des problèmes. C'est un prolétaire, il n'a pas de travail et cette pièce parle aussi des problèmes de l'homme avec la femme quand il ne peut lui donner ce qu'il pense qu'il doit donner à une femme. C'est-à-dire la maison, le travail, le plaisir. Il se rend compte que la révolution communiste - ou n'importe quelle révolution - n'a pas prévu ce cas. Il $\mathrm{y}$ a des solutions pour les problèmes d'argent, pour les problèmes de l'éducation mais pour les problèmes intimes, profonds de l'homme : il n'y a pas de solution.

4 La pièce va suivre ces thèmes.

Quel a été votre travail?

Nous avons travaillé sur des improvisations, de ce que chacun de la troupe a retenu de la pièce après lecture.

Nous avons aussi travaillé avec des ateliers de voix, de mouvement, de danse et de chant. Pendant six mois : trois heures pour tous les acteurs et cinq heures pour les acteurs principaux. À la fin, on a fait l'écriture et le montage des scènes. Les chorégraphies et les musiques sont d'auteurs espagnols très jeunes, comme le metteur en scène et les deux assistants.

Quelle est l'histoire de votre théâtre?

Il y a longtemps qu'il y a un Théâtre universitaire à Murcie. En 1970, pendant la dictature du général Franco, c'était un théâtre de combat contre la censure. Il y a deux ans, on a fondé une section théâtre à l'Université et on fait des projets. Mais l'idée de cette pièce vient du Théâtre universitaire et presque tous les acteurs aussi. À Murcie, il n'y a pas beaucoup de gens qui font du théâtre. Ce n'est que la seconde fois que nous représentons cette pièce. En Espagne, elle avait été moins bien accueillie qu'ici, il y 
avait une sorte d'irrespect pour la pièce. C'était dans un village où personne ne connait les mécanismes du théâtre. La langue est un problème, mais il y a des gens qui sans comprendre l'espagnol comprennent la pièce.

10 Quels sont vos projets pour ce spectacle?

11 Nous allons jouer en Espagne, au Pays Basque, faire une tournée. 